\title{
Keseimbangan mekanisme fotosintesis dan carnivory pada tumbuhan kantung semar: suatu kajian pustaka
}

\author{
Balance of photosynthetic and carnivory mechanisms in pitcher plant: a review
}

\author{
Syafiq Ubaidillah ${ }^{1}$, Luluk Mukarramah ${ }^{2}$, Dian Al Ghifari Perwitasari ${ }^{1}$, Siti Rohimah ${ }^{1}$, Fefi Eka Wardani ${ }^{1}$, \\ Mukhamad Su'udi ${ }^{1 *}$ \\ ${ }^{1}$ Jurusan Biologi, Fakultas Matematika dan Ilmu Pengetahuan Alam, Universitas Jember, Indonesia - 64121 \\ ${ }^{2}$ Program Studi Pendidikan Biologi, Fakultas Keguruan dan Ilmu Pendidikan, Universitas Jember, Indonesia - 64121 \\ *Email: msuudi52@gmail.com
}

Diterima 28 Juni 2019 Disetujui 31 Agustus 2020

\section{INTISARI}

Kantung semar (Nepenthes sp.) merupakan tumbuhan karnivora yang mampu membentuk struktur kantung ketika nutrisi dalam lingkungan tidak mencukupi untuk mendukung pertumbuhan dan perkembangannya. Tujuan penyusunan artikel ini adalah mengkaji karakterisitik morfologi dan fisiologi Nepenthes (karakter fotosisntesis), serta mekanisme carnivory dengan beberapa enzim pencernaan yang dihasilkan. Berdasarkan kajian yang telah dilakukan sebelumnya, diketahui bahwa Nepenthes mampu melakukan mekanisme carnivory dan fotosintesis secara bersamaan. Tumbuhan ini mendapatkan nitrogen organik dan nitrogen anorganik melalui kedua mekanisme tersebut. Berdasarkan struktur anatomi daun, tumbuhan ini diduga sebagai tumbuhan C3 tetapi memiliki laju rata-rata fotosintesis lebih rendah dari tumbuhan C3 non-karnivora. Mekanisme carnivory pada Nepenthes dibantu oleh beberapa enzim di antaranya glukanase, kitinase, protease, nuklease, fosfatase, lipase dan peroksidase.

Kata kunci: C3, Carnivory, Fotosintesis, Nepenthes

\begin{abstract}
The pitcher plants (Nepenthes sp.) are carnivorous plants. They can form a sac when nutrients in the environment are insufficient to support their growth and development. The purpose of the preparation of this article is to examine the characteristics of Nepenthes morphology and physiology (the character of photosynthesis), as well as the carnivory mechanism with several digestive enzymes produced. Based on the studies, Nepenthes can do carnivory and photosynthetic mechanisms simultaneously. This plant gets organic nitrogen and inorganic nitrogen through these two mechanisms. Based on the anatomical structure of the leaves, this plant is thought to be a C3 plant but has a lower rate of photosynthesis than non-carnivorous C3 plants. The carnivory mechanism in Nepenthes assisted by several enzymes including glucanase, chitinase, proteases, nuclease, phosphatase, lipase, and peroxidase.
\end{abstract}

Keywords: C3, Carnivory, Photosynthesis, Nepenthes

\section{PENDAHULUAN}

Kantung semar (Nepenthes sp.) merupakan tumbuhan unik yang tergolong dalam redlist konservasi IUCN (International Union for Conservation of Nature) dengan status kritis (critically endangered). Berdasarkan Peraturan Pemerintah Republik Indonesia No.7 Tahun 
1999 tentang pengawetan jenis tumbuhan dan satwa, serta Peraturan Menteri Lingkungan Hidup dan Kehutanan Republik Indonesia No. P.20/MENLHK/SETJEN/KUM.1/6/2018 tentang jenis tumbuhan dan satwa yang dilindungi, Nepenthes merupakan salah satu genus yang dilindungi oleh pemerintah Indonesia. Hal ini sejalan dengan peraturan Konvensi Perdagangan Internasional Spesies Terancam Punah (Convention on International Trade in Endangered Species) (CITES) (Lestariningsih \& Setyaningsih, 2017). Distribusi Nepenthes meliputi wilayah Madagaskar, Asia Tenggara hingga Australia bagian utara (Osunkoya \& Muntassir, 2017). Setidaknya terdapat lebih dari 100 spesies yang telah berhasil dideskripsikan di daerah Asia Tenggara (Bauer et al., 2012; McPherson, 2009; Phillipps et al., 2008) dengan distribusi keanekaragaman terbesar terletak di Kalimantan dan Sumatra (Bonhomme et al., 2011). Habitat Nepenthes meliputi dataran rendah pesisir, hutan, tebing, dan dataran tinggi dengan tingkat endemisme yang tinggi (Arimy et al., 2017; Bonhomme et al., 2011). Terdapat 36 spesies Nepenthes yang telah diidentifikasi di pulau Kalimantan, lebih dari 30 spesies di pulau Sumatra, dan 21 spesies di Filipina (Bauer et al., 2012; Clarke, 1997; McPherson, 2009). Selain itu, Nepenthes juga ditemukan di Sulawesi, Maluku, Jawa, dan Papua Nugini (Mansur, 2006).

Nepenthes merupakan tumbuhan dikotil dengan karakter yang khas dibandingkan dengan tumbuhan lain. Tumbuhan ini digolongkan sebagai tumbuhan karnivora karena kemampuannya untuk menangkap dan mencerna mangsa untuk dijadikan sebagai sumber nutrisi. Nepenthes membutuhkan serangga untuk memenuhi kebutuhan nutrisi (Arimy et al., 2017; Clarke, 1997). Ketika kondisi lingkungan yang kurang menguntungkan akibat kurangnya nutrisi esensial, yaitu Nitrogen (N) dan Fosfor (P), tumbuhan ini akan memodifikasi daunnya membentuk struktur kantung. Hal ini bertujuan untuk menjebak mangsa yang hinggap dan mencerna nutrisi penting bagi metabolismenya. Kemampuan ini menyebabkan kantong semar mampu hidup pada kondisi lingkungan yang kurang menguntungkan (miskin unsur hara) dibandingkan tumbuhan lain yang cenderung tidak mampu bertahan (Juniper et al., 1989).

Nepenthes merupakan tumbuhan berklorofil dan mampu memfiksasi $\mathrm{CO}_{2}$ melalui proses fotosintesis. Fotosintesis merupakan proses kompleks untuk mendapatkan karbon organik yang sangat penting dalam proses metabolisme. Meskipun sumber karbon telah diperoleh dari hasil mencerna mangsa, organisme ini tetap melakukan fotosintesis. Hal ini bertujuan agar Nepenthes memperoleh sumber karbon yang lebih banyak untuk proses pertumbuhan dan perkembangannya. Mekanisme carnivory dan fotosintesis pada tumbuhan karnivora menyebabkan peningkatan kandungan nitrogen pada daun setelah terjadinya mekanisme carnivory (Givnish et al., 1984), sehingga seharusnya terjadi peningkatan biomassa maupun luas area daun atau total laju fotosintetik. Namun hal tersebut tidak terbukti bahkan mekanisme carnivory tidak meningkatkan kandungan $\mathrm{N}$ pada jaringan (Adamec, 1997), sehingga diduga terdapat mekanisme yang sangat kompleks dalam mengatur dan menyeimbangkan mekanisme carnivory dan fotosintesis pada daun Nepenthes.

\section{PEMBAHASAN}

\section{Morfologi kantung pada Nepenthes}

Nepenthes tergolong ke dalam tumbuhan liana (merambat) dengan tumbuh secara terestrial atau menempel (epifit) pada batang atau ranting pohon. Tumbuhan ini memiliki bunga berumah dua, yaitu bunga jantan dan betina terpisah pada individu yang berbeda (Mansur, 2006). Daun termasuk daun tunggal, berbentuk lanset atau sudip, dengan sulur terdapat pada ujung daunnya, dan tangkai daun yang tidak selalu ada (Clarke, 2001). Nepenthes digolongkan sebagai tumbuhan heterofili, yaitu memiliki daun untuk fotosintesis dan daun lain yang termodifikasi untuk menangkap mangsa. Batang Nepenthes memiliki ruas-ruas memanjang yang bisa dimanfaatkan untuk menempel dan memanjat, 
dan ketika dewasa tumbuhan ini memproduksi bunga dan buah (Clarke, 1997). Seedling atau tumbuhan muda pada beberapa jenis spesies membentuk roset yang dapat menghasilkan daun maupun kantung pada tangkai yang pendek. Kantung Nepenthes secara umum terdiri dari kantung (pitcher), bibir (peristom), dan tutup (lip) (Gambar 1) (Clarke, 2001), meskipun bentuk kantung bervariasi pada setiap jenis. Struktur kantung (pitcher) pada Nepenthes terbentuk pada ujung daun dan terbagi menjadi tiga bagian utama. Bagian paling atas dan licin yaitu peristome (pitcher rim) yang berfungsi untuk menarik dan menjebak mangsa. Bagian ke dua yaitu dinding dalam yang lunak, berfungsi untuk mencegah mangsa kabur, dan bagian bawah yang terisi cairan asam viscoelastis untuk mencerna mangsa yang tertangkap (Gambar 1) (Moran et al., 2012; Pavlovic et al., 2011).

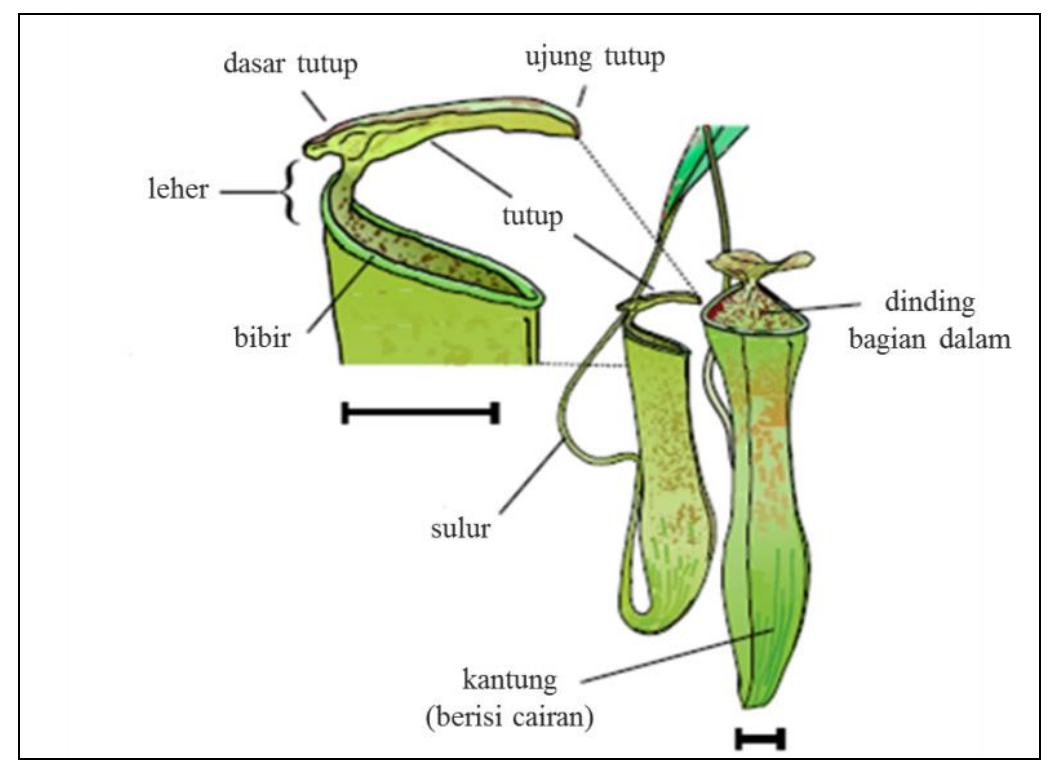

Gambar 1. Morfologi kantung pada Nepenthes sp. (Bauer et al., 2015)

Kantung yang terbentuk pada Nepenthes umumnya dibedakan menjadi dua macam berdasarkan letaknya, yaitu kantung atas dan kantung bawah. Kantung atas dipakai untuk menyebutkan struktur kantung yang terbentuk pada batang tumbuhan dewasa yang memanjat dengan bentuk kantung lebih ramping seperti corong. Kantung bawah adalah istilah untuk menyebutkan struktur kantung yang terbentuk pada batang muda yang tumbuh dekat permukaan tanah, dan kadang-kadang berkelompok membentuk roset (Clarke, 1997). Umumnya kantung atas dan bawah memiliki bentuk yang sedikit berbeda, namun perbedaan struktur kantung atas dan bawah tidak selalu jelas (Jebb \& Chee, 1997). Variasi bentuk kantung juga dilengkapi dengan variasi warna kantung pada beberapa spesies Nepenthes, mulai merah hingga hijau dengan perbedaan warna pada kantung bagian atas dan bawah (Gilbert et al., 2018).

Morfologi beberapa spesies dalam genus Nepenthes meskipun dalam genus yang sama menunjukan adanya perbedaan morfologi. $N$. gracilis memiliki bentuk batang segitiga dengan warna hijau sampai coklat kemerahan, daun tebal dengan bentuk lanset, kantung atas dan kantung bawah berbentuk silindris dengan warna hijau, coklat atau kemerahan (Gambar 2-a). $N$. mirabilis memiliki batang berbentuk bulat, berwarna hijau, merah atau hijau kemerahan. Daun tipis dengan bentuk lanset, dan permukaan licin. Kantung berwarna hijau atau merah (Gambar 2-b). N. rafflesiana memiliki batang berbentuk bulat dengan warna hijau, merah, atau coklat. Tutup (lip) berbentuk oval dan bersayap. Kantung berbentuk corong, bersayap, berwarna hijau dengan lurik coklat (Gambar 2-c). N. ampullaria memiliki batang silindris berwarna 
hijau kecoklatan. Daun tebal, berwarna hijau dengan bentuk lanset. Tutup (lip) berbentuk elips dan bersayap. Kantung berwarna hijau, atau hijau dengan bibir (peristom) berwarna merah (Gambar 2-d) (Lestariningsih \& Setyaningsih, 2017).

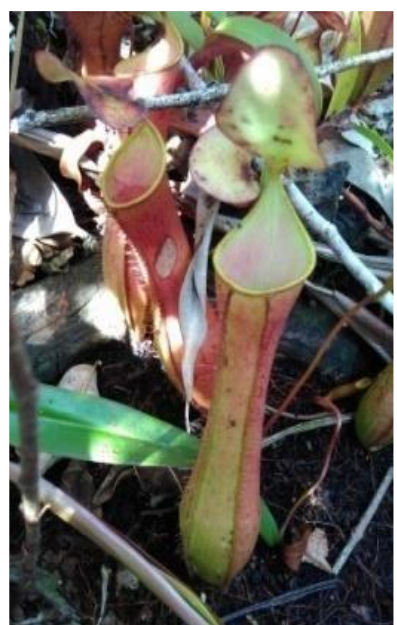

(a)

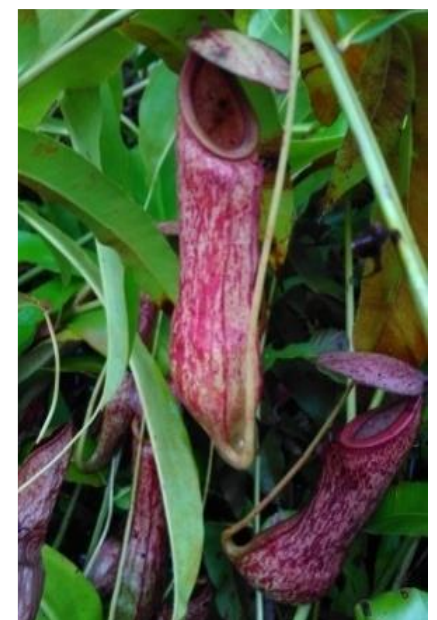

(b)

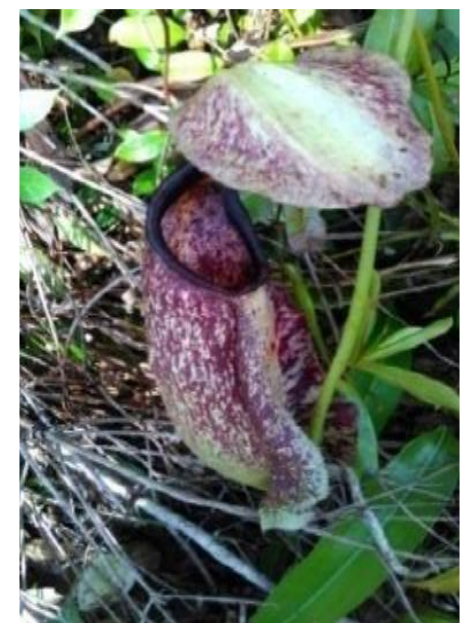

(c)

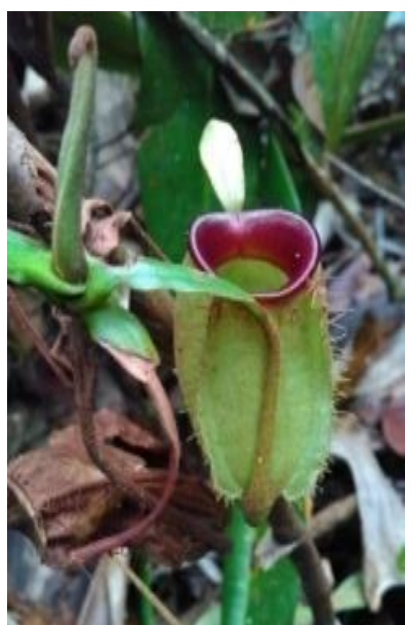

(d)

Gambar 2. Jenis-jenis Nepenthes yang memiliki karakter morfologi berbeda. (a) N. gracilis; (b) N. mirabilis; (c) N. rafflesiana; (d) N. ampullaria. (Lestariningsih \& Setyaningsih, 2017)

\section{Anatomi daun dan mekanisme fotosintesis Nepenthes}

Nepenthes mampu bertahan hidup pada lingkungan dengan jumlah air dan cahaya matahari yang melimpah tetapi kandungan nutrisi yang minim. Hasil penelitian Clarke, (1997) menunjukkan bahwa Nepenthes gagal membentuk struktur kantung ketika cahaya matahari dan kelembaban udara terlalu rendah serta nutrisi di lingkungan terlalu tinggi. Mekanisme fotosintesis dan carnivory pada Nepenthes dapat terjadi secara simultan dan saling melengkapi.

Ellison dan Gotelli (2001) melaporkan struktur daun maupun kantung pada tumbuhan tersebut dapat melakukan fotosintesis secara bersamaaan. Hal ini dikarenakan adanya klorofil yang terkandung dalam kedua struktur tersebut. Akan tetapi, kerapatan stomata pada bagian kantung lebih rendah dibandingkan pada bagian helaian daun (Pavlovič et al., 2007). Tumbuhan ini melakukan fotosintesis dengan memanfaatkan $\mathrm{CO}_{2}$ bebas sebagai sumber karbon, tetapi tumbuhan ini tetap memerlukan nutrisi esensial seperti nitrogen atau yang lainnya (He \& Zain, 2012). Penyerapan nutrisi dapat dilakukan melalui akar ataupun dengan mencerna mangsa melalui struktur kantung yang terbentuk ketika nutrisi di lingkungan sangat tidak mencukupi. Nepenthes dapat mengambil nutrisi dari mangsa yang terperangkap dalam kantung dan mengalokasikan nitrogen $(\mathrm{N})$ ke jaringan yang lain. Nitrogen dilepaskan dari hidrolisis urea menjadi ammonia dan $\mathrm{CO}_{2}$ (Yilamujiang et al., 2017). Penelitian He dan Zain, (2012) menyebutkan bahwa tumbuhan yang tidak memiliki struktur kantung hanya mampu menyerap $\mathrm{N}$ anorganik saja, sedangkan Nepenthes alata yang memiliki struktur kantung memiliki keuntungan dibandingkan spesies lain, karena suplai $\mathrm{N}$ organik dapat diperoleh dari mangsa yang tertangkap dan $\mathrm{N}$ anorganik dalam bentuk $\mathrm{NO}_{3}{ }^{-}$diserap melalui akar. Fotosintesis masih berlangsung pada Nepenthes sekalipun sumber karbon telah didapat melalui mangsa yang tertangkap.

Tidak banyak penelitian yang menjelaskan secara langsung mengenai mekanisme fotosintesis dari Nepenthes. Beberapa penelitian 
mengenai fotosintesis pada Nepenthes menyebutkan bahwa Nepenthes menggunakan jalur mekanisme fotosintesis C3 dengan bantuan enzim Rubisco dalam proses fiksasi karbon dan produk organik pertama yang dihasilkan adalah senyawa berkarbon tiga, yaitu asam 3fosfogliserat (Baby et al., 2017; Campbell \& Reece, 2011; Clarke \& Moran, 2016; He \& Zain, 2012; Moran et al., 2001; Osunkoya \& Muntassir, 2017; Pavlovic et al., 2011). Penelitian Moran et al., (2001) menggunakan isotop atom karbon stabil $\delta^{13} \mathrm{C}$ pada daun Nepenthes mengindikasikan bahwa $N$. albomarginata dan $N$. raflesiana memiliki kisaran nilai isotop karbon stabil $\delta^{13} \mathrm{C}$ yang serupa dengan tumbuhan $\mathrm{C}$ 3. Isotop karbon $\mathrm{C}$ pada daun berkaitan dalam kapasitas fotosintesis. Hubungan ini dirumuskan dalam sebuah model yang menghubungkan fotosintesis ke isotop karbon stabil $\delta^{13} \mathrm{C}$ melalui perhitungan $\mathrm{Ci} / \mathrm{Ca}(\mathrm{Ci}$ adalah tekanan parsial $\mathrm{CO}_{2}$ interseluler, $\mathrm{Ca}$ adalah tekanan parsial $\mathrm{CO}_{2}$ ambient) (Moran et al., 2001). Osunkoya dan Muntassir, (2017) yang mengamati anatomi daun Nepenthes menyebutkan secara implisit bahwa Nepenthes merupakan tumbuhan $\mathrm{C} 3$ dengan anatomi daun yang tersusun dari kutikula, epidermis, jaringan mesofil (palisade dan spons), dan pembuluh angkut. Namun Schulze et al., (1999) menjelaskan bahwa Nepenthes memiliki struktur bundle sheath yang diketahui sebagai lokasi enzim Rubisco pada tumbuhan C4. Enzim PEP karboksilase yang berperan pada awal tahapan fotosintesis terdapat di jaringan mesofil. $\mathrm{CO}_{2}$ ditambahkan oleh PEP karboksilase ke fosfoenolpiruvat untuk membentuk senyawa berkarbon empat, yaitu asam oksaloasetat. Hasil fiksasi $\mathrm{CO}_{2}$ dari mesofil akan diekspor ke bundle sheath melalui plasmodesma. Senyawa berkarbon 4 di dalam bundle sheath akan melepaskan $\mathrm{CO}_{2}$, kemudian $\mathrm{CO}_{2}$ akan diasimilasi kembali ke dalam materi organik oleh enzim Rubisco dalam siklus Calvin (Campbell \& Reece, 2011).

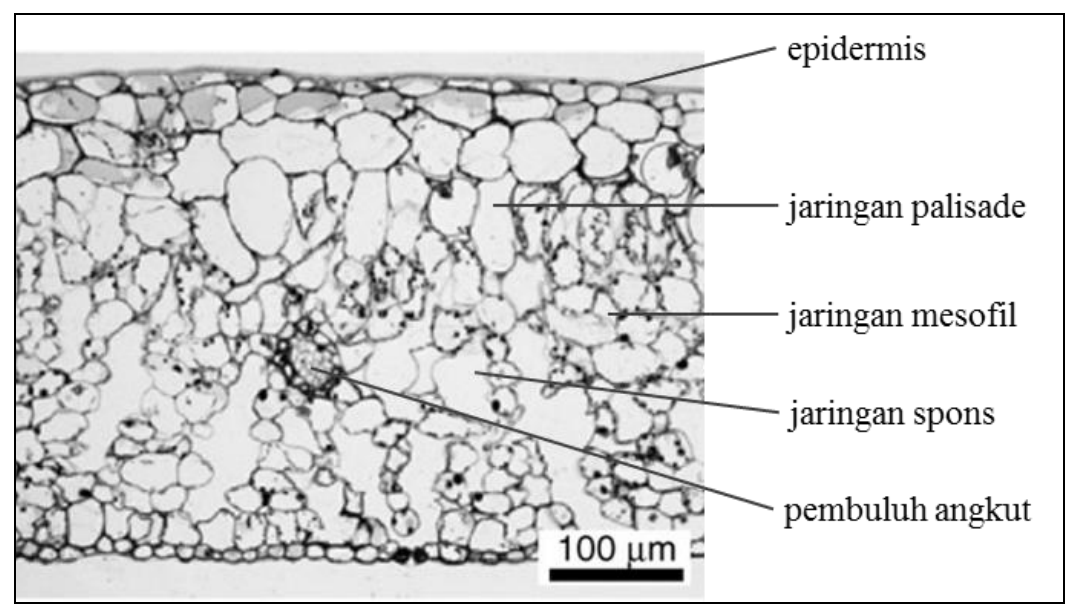

Gambar 3. Penampang melintang lamina daun N. alata dengan jaringan palisade dan spons (Pavlovič et al., 2007)

Anatomi daun N. alata (Gambar 3) menunjukkan adanya jaringan epidermis, jaringan mesofil (palisade dan spons) serta pembuluh angkut yang kecil. Apabila dibandingkan dengan penampang melintang daun tumbuhan $\mathrm{C} 3$ dan $\mathrm{C} 4$, maka anatomi daun Nepenthes lebih mirip dengan anatomi daun tumbuhan C3 pada umumnya. Schulze et al., (1999) menjelaskan bahwa Nepenthes memiliki bundle sheath, namun belum ada data ataupun penelitian yang menyebutkan bahwa Nepenthes merupakan tumbuhan C4. Selain itu, tidak semua tumbuhan yang memiliki bundle sheath merupakan tumbuhan C4. Nomura et al., (2000) menjelaskan bahwa daun jagung dan padi samasama memiliki jaringan mesofil dan bundle sheath, tetapi mekanisme jalur fotosintesis kedua tumbuhan tersebut berbeda. Jagung merupakan tumbuhan $\mathrm{C} 4$ dan padi merupakan tumbuhan $\mathrm{C} 3$ yang mempunyai perbedaan dalam fiksasi $\mathrm{CO}_{2}$. Fiksasi awal $\mathrm{CO}_{2}$ pada tumbuhan $\mathrm{C} 3$ yang dikatalisis oleh enzim Rubisco terjadi pada 
jaringan mesofil. Fiksasi awal $\mathrm{CO}_{2}$ pada tumbuhan $\mathrm{C} 4$ dikatalisis oleh enzim fosfoenol piruvat karboksilase di jaringan mesofil, kemudian hasil fiksasi diangkut ke bundle sheath, tempat terjadinya siklus Calvin yang dikatalisis oleh enzim Rubisco. Hal ini menyebabkan bundle sheath tidak dapat menjadi patokan untuk menentukan mekanisme fotosintesis suatu tumbuhan sebagai jalur C3 atau C4. Beberapa penelitian tersebut untuk sementara menyimpulkan bahwa Nepenthes menggunakan mekanisme fotosintesis jalur C3.

Sebagian besar tumbuhan karnivora seperti Nepenthes menunjukkan laju fotosintesis yang sangat rendah. Nepenthes memang diduga merupakan tumbuhan yang tergolong $\mathrm{C} 3$, namun laju rata-rata fotosintesis pada Nepenthes di bawah laju rata-rata fotosintesis tumbuhan C3. Laju fotosintesis Nepenthes berkisar 2 hingga 5 kali lebih rendah daripada tumbuhan nonkarnivora lainnya (He \& Zain, 2012), terutama pada struktur daun yang termodifikasi menjadi kantung. Daun yang termodifikasi menjadi kantung memiliki laju fotosintesis rata-rata lebih rendah daripada daun yang tidak termodifikasi (lamina) pada tumbuhan yang sama (He \& Zain, 2012; Pavlovic et al., 2011).

\section{Mekanisme carnivory}

Nepenthes adalah tumbuhan karnivora yang mampu hidup pada kondisi lingkungan dengan unsur hara yang terbatas. Ketika daya dukung nutrisi di lingkungan kurang mencukupi, tumbuhan ini akan memodifikasi daunnya membentuk struktur khusus menyerupai kantung untuk menangkap, mencerna, dan menyerap nutrisi dari mangsa yang masuk ke dalamnya. Proses penyerapan nutrisi melalui mekanisme carnivory pada Nepenthes sp. melibatkan berbagai macam jenis enzim dan mekanisme yang kompleks. Aktivitas carnivory bermanfaat sebagai sumber serapan $\mathrm{N}$ bagi Nepenthes. Kuantitas mangsa yang terperangkap pada kantung berhubungan dengan laju penyerapan nutrisi termasuk laju fotosintesis (Pavlovič et al., 2014).

Reseptor yang terdapat pada bagian dalam kantung mendeteksi adanya mangsa atau patogen yang kemudian menghasilkan sekresi enzim pencernaan ke dalam rongga kantung. Glukanase dan kitinase mencerna eksoskeleton mangsa dan dinding sel dari patogen dan serpihan tumbuhan yang tertangkap. Pencernaan protein dan asam nukleat dikatalis oleh protease, nuklease, dan fosfatase, sehingga bahan baku untuk prekursor nitrogen dan fosfat yang sangat dibutuhkan oleh tumbuhan dapat tersedia. Lipase yang kemungkinan berasal dari mikrobiom yang ada juga berkontribusi untuk menguraikan lipid menjadi asam lemak dan gliserol. Mikrobiom tersebut berasal dari cairan yang terdapat pada kantung Nepenthes (Lee et al., 2016).

Lee et al., (2016) melaporkan beberapa protein yang disekresikan pada bagian dalam kantung Nepenthes. Banyak enzim hidrolitik yang berperan dalam pencernan mangsa dan juga memiliki sifat anti bakteri dan atau anti jamur yang dianggap sebagai protein yang berhubungan dengan patogenesis. Hubungan antara karnivora dan patogenesis selanjutnya didukung oleh adanya beberapa potein yang berhubungan khusus dengan patogenesis, seperti peroksidase, hevein (protein pengikat kitin), thaumatin-like protein, dan protein LRR (Tabel 1). Peroksidase berkontribusi untuk pertahanan terhadap patogen dengan menghasilkan ROS.

Tabel 1. Beberapa protein yang disekresikan Nepenthes sp. (Lee et al., 2016)

\begin{tabular}{cll}
\hline \multicolumn{1}{c}{ Proses } & \multicolumn{1}{c}{ Protein } & Kelas/ Fungsi \\
\hline Metabolisme protein & Nepenthesin-1 (Nep 1) & Aspartik protease \\
& Nepenthesin-2 (Nep 2) & Aspartik protease \\
& Nepenthesin-3 (Nep 3) & Aspartik protease \\
& Nepenthesin-4 (Nep 4) & Aspartik protease \\
& Nepenthesin-5 (Nep 5) & Aspartik protease \\
& Neprosin-1 $($ Npr 1$)$ & Prolil endoprotease
\end{tabular}


Tabel 1 (lanj.). Beberapa protein yang disekresikan Nepenthes sp. (Lee et al., 2016)

\begin{tabular}{|c|c|c|}
\hline Proses & Protein & Kelas/ Fungsi \\
\hline \multirow{5}{*}{$\begin{array}{l}\text { Metabolisme asam } \\
\text { nukleat }\end{array}$} & Neprosin-2 (Npr 2) & Prolil endoprotease \\
\hline & Serine carboxy-peptidase (SCP 1) & S10 asidik peptidase \\
\hline & Purple acid phosphatase (PAP 1) & Metalofosfatase \\
\hline & Ribunuclease S-like (RNAseS) & Mensekresi RNAse/mendapatkan fosfat \\
\hline & Endoglucanase 2 (Endo 2) & S1-P1 nuklease/memecah RNA dan ssDNA \\
\hline \multirow{4}{*}{$\begin{array}{l}\text { Metabolisme } \\
\text { polisakarida }\end{array}$} & B-1, 3-glucanase, Glu 1 & Glikosida hidrolase 17/pertahanan terhadap patogen \\
\hline & Acidic Chitinase, Chit 3 & Glikosida hidrolase 18/pertahanan terhadap patogen \\
\hline & Chitinase, Chit 1 & Glikosida hidrolase 19/pertahanan terhadap patogen \\
\hline & Domon-like domain, Doml & Heme-binding motif/hidrolase glikosida \\
\hline \multirow{4}{*}{$\begin{array}{l}\text { Pathogenesis/pertahanan } \\
\text { inang } \\
\text { Peroksidase }\end{array}$} & Thaumatin-like protein, TLPI & Aktivitas aktifungal \\
\hline & Hevein, Hev 1 & Pengikatan kitin/aktivitas antifungal \\
\hline & Cat. Peroxidase 1, Prx 1 & Heme-containing/oksidasi \\
\hline & Cat. Peroxidase 2, Prx 2 & Heme-containing/oksidasi \\
\hline \multirow[t]{2}{*}{ Sinyal transduksi } & $\begin{array}{l}\text { Leu-rich repeat protein kinase, } \\
\text { RPKI }\end{array}$ & Ser/Thr Kinase/plant dev./pertahanan terhadap patogen \\
\hline & Leu-rich repeat protein, $L R R 1$ & Possible protein kinase/inhibitor ribonukleaase \\
\hline \multirow[t]{4}{*}{ Metabolisme energi } & ADP/ATP translocase, $A D T 1$ & Pertukaran ADP/ATP \\
\hline & $\begin{array}{l}\text { Glyceraldehyde-3-phosphate } \\
\text { dehydrogenase, GDP } 1\end{array}$ & Pengikatan NAD/glikolisis/glikoneogenesis \\
\hline & $\begin{array}{l}\text { ATP syntasel } H^{+} \text {-ATPase subunit } \beta \text {, } \\
A T P B\end{array}$ & Sintesis ATP/membran-bound proton-pump \\
\hline & Enolase, Eno 1 & Konversi 2-fosfo-D-giserat \\
\hline \multirow[t]{3}{*}{ Transport protein } & Actin, Act 1 & Sitoskeleton \\
\hline & Tic20-like protein, Tic 20 & Chloroplast import protein \\
\hline & Protein transporter, $\mathrm{Secl}$ & Vesicle tafficking/ sekresi \\
\hline \multirow{4}{*}{$\begin{array}{l}\text { Translokasi/sintesis } \\
\text { protein }\end{array}$} & Elongation faktor 1-alpha, EF la & GTP-binding elongation factor \\
\hline & Elongation factor 2, EF 2 & GTP-dependent ribosomal tranlocation \\
\hline & 40s ribosomal protein $s 14, \mathrm{RS} 14$ & Sintesis protein \\
\hline & Chaperon protein Hsp90 & Protein folding \\
\hline \multirow[t]{2}{*}{ Transkripsi/ regulasi gen } & Histone acetyltransferase, HAC 1 & Regulator transkripsi asetilat, histon \\
\hline & Auxin respose factor, $A R F 1$ & Faktor transkripsi/ auxin response factor \\
\hline
\end{tabular}

Oksidasi protein mangsa oleh ROS yang dihasilkan peroksidase dapat meningkatkan kerentanan terhadap degradasi oleh protease. Hevein domain mengikat kitin dan memperlihatkan aktivitas anti jamur. Thaumatinlike protein juga cenderung memiliki peran antijamur yang serupa. Leu-rich repeat (LRR) receptor-like protein kinase (RPK1) dapat merangsang sekresi enzim ke dalam kantung, setelah merasakan keberadaan mangsa atau patogen, dan $\mathrm{H}^{+}$-ATPase yang terikat pada membran dapat berfungsi sebagai pemompa proton untuk pengasaman cairan dalam kantung Nepenthes. Kedua protein tersebut berhubungan dengan membran. Protein yang lain terlibat dalam metabolisme energi, transportasi protein, ekspresi dan sintesis protein (Tabel 1) (Lee et al., 2016).

\section{SIMPULAN}

Nepenthes secara morfologi memiliki struktur yang unik, yaitu adanya struktur menyerupai kantung yang merupakan modifikasi dari daun. Kantung tersebut berfungsi untuk menangkap mangsa yang secara umum strukturnya terdiri dari kantung (pitcher), bibir (peristom), dan tutup (lip). Nepenthes mampu melakukan mekanisme carnivory dan fotosintesis secara bersamaan. Tumbuhan ini mendapatkan $\mathrm{N}$ organik dan $\mathrm{N}$ anorganik melalui kedua mekanisme tersebut. Berdasarkan struktur anatomi daunnya tumbuhan ini diduga sebagai tumbuhan $\mathrm{C} 3$ tetapi memiliki laju rata-rata fotosintesis lebih rendah dari tumbuhan C3 nonkarnivorous. Mekanisme carnivory Nepenthes dibantu oleh beberapa enzim diantaranya 
glukanase, kitinase, protease, nuklease, fosfatase, lipase dan peroksidase.

\section{KEPUSTAKAAN}

Adamec L. 1997. Mineral nutrition of carnivorous plants: a review. The Botanical Review 63(3).

Arimy NQ, Nisyawati, Metusala D. 2017. Comparison of leaf anatomy on some Nepenthes spp. (Nepenthaceae) from highland and lowland habitat in Indonesia. AIP Conference Proceedings. American Institute of Physics Inc., 030111. DOI: 10.1063/1.4991215.

Baby S, Johnson AJ, Zachariah EJ, Hussain AA. 2017. Nepenthes pitchers are $\mathrm{CO}_{2}$-enriched cavities, emit CO2 to attract preys. Scientific Reports 7(1): 1-10. DOI: 10.1038/s41598017-11414-7

Bauer U, Clemente CJ, Renner T, Federle W. 2012. Form follows function: morphological diversification and alternative trapping strategies in carnivorous Nepenthes pitcher plants. Journal of Evolutionary Biology 25(1): $\quad 90-102 . \quad$ DOI: $10.1111 /$ j.14209101.2011.02406.x.

Bauer U, Paulin M, Robert D, Sutton GP. 2015. Mechanism for rapid passive-dynamic prey capture in a pitcher plant. Proceedings of the National Academy of Sciences of the United States of America 112(43): 13384-13389. DOI: $10.1073 /$ pnas.1510060112.

Bonhomme V, Pelloux-Prayer H, Jousselin E, Forterre Y, Labat J-J, Gaume L. 2011. Slippery or sticky? Functional diversity in the trapping strategy of Nepenthes carnivorous plants. New Phytologist 191(2): 545-554. DOI: $\quad 10.1111 / \mathrm{j} .1469-$ 8137.2011.03696.x.

Campbell NA, Reece JB. 2011. Biology. Pearson Benjamin Cummings: USA

Clarke C. 2001. Nepenthes of Sumatra and Peninsular Malaysia. Natural History Publications (Borneo): Kinabalu, Malaysia.

Clarke C, Moran JA. 2016. Climate, soils and vicariance - their roles in shaping the diversity and distribution of Nepenthes in Southeast Asia. Plant and Soil 403(1-2): 37-51. DOI: 10.1007/s11104-015-2696-x.

Clarke CM. 1997. Nepenthes of Borneo. Natural History Publications: Kota Kinabalu, Malaysia.

Ellison AM, Gotelli NJ. 2001. Evolutionary ecology of carnivorous plants. Trends in Ecology and Evolution 16(11): 623-629. DOI: 10.1016/S0169-5347(01)02269-8.

Gilbert KJ, Nitta JH, Talavera G, Pierce NE. 2018. Keeping an eye on coloration: Ecological correlates of the evolution of pitcher traits in the genus Nepenthes (Caryophyllales). Biological Journal of the Linnean Society 123(2): 321-337. DOI: 10.1093/biolinnean/blx142.

Givnish TJ, Burkhardt EL, Happel RE, Weintraub JD. 1984. Carnivory in the bromeliad Brocchinia reducta, with a cost/benefit model for the general restriction of carnivorous plants to sunny, moist, nutrient-poor habitats. American Naturalist 124(4): 479-497. DOI: 10.1086/284289.

He J, Zain A. 2012. Photosynthesis and Nitrogen Metabolism of Nepenthes alata in response to inorganic $\mathrm{NO}_{3}$ - and organic prey $\mathrm{N}$ in the greenhouse. International Scholarly Research Notices ISRN Botany 2012: 8. DOI: $10.5402 / 2012 / 263270$.

Jebb M, Chee M. 1997. A skeletal revision of Nepenthes (Nepenthaceae). Blumea: Biodiversity, Evolution and Biogeography of Plants 42(1): 1-106

Juniper B, Robins R, Joel D. 1989. The carnivorous plants. Academic Press: London.

Lee L, Zhang Y, Ozar B, Sensen CW, Schriemer DC. 2016. Carnivorous nutrition in Pitcher Plants (Nepenthes spp.) via an unusual complement of endogenous enzymes. Journal of Proteome Research 15(9): 31083117. DOI: 10.1021/acs.jproteome.6b00224.

Lestariningsih N, Setyaningsih D. 2017. Explorative study of tropical pitcher plants (Nepenthes sp.) types and insects that 
trapped inside in Sebangau National Park Palangka Raya Central Kalimantan. Journal of Physics: Conference Series. Institute of Physics Publishing, $795 . \quad$ DOI: 10.1088/1742-6596/795/1/012062.

Mansur M. 2006. Nepenthes: Kantong semar yang unik. Penebar Swadaya: Jakarta

McPherson S. 2009. Pitcher plants of the Old World. Redfern Natural History Productions: Poole.

Moran JA, Clarke C, Greenwood M, Chin L. 2012. Tuning of color contrast signals to visual sensitivity maxima of tree shrews by three Bornean highland Nepenthes species. Plant Signaling \& Behavior 7(10): 12671270. DOI: $10.4161 /$ psb.21661.

Moran JA, Merbach MA, Livingston NJ, Clarke CM, Booth WE. 2001. Termite prey specialization in the pitcher plant Nepenthes albomarginata - Evidence from stable isotope analysis. Annals of Botany 88(2): 307-311. DOI: 10.1006/anbo.2001.1460

Nomura M, Katayama K, Nishimura A, Ishida Y, Ohta S, Komari T, Miyao-Tokutomi M, Tajima S, Matsuoka M. 2000. The promoter of $\mathrm{rbcS}$ in a $\mathrm{C} 3$ plant (rice) directs organspecific, light-dependent expression in a $\mathrm{C} 4$ plant (maize), but does not confer bundle sheath cell-specific expression. Plant Molecular Biology 44(1): 99-106. DOI: 10.1023/A:1006461812053.

Osunkoya OO, Muntassir NA. 2017. Comparative anatomy of the assimilatory organs of Nepenthes species. Australian Journal of Botany 65(1): $67 . \quad$ DOI: 10.1071/BT16157.

Pavlovič A, Krausko M, Libiaková M, Adamec L. 2014. Feeding on prey increases photosynthetic efficiency in the carnivorous sundew Drosera capensis. Annals of Botany 113(1): 69-78. DOI: $10.1093 / \mathrm{aob} / \mathrm{mct} 254$.

Pavlovič A, Masarovičová E, Hudák J. 2007. Carnivorous syndrome in Asian pitcher plants of the genus Nepenthes. Annals of Botany 100(3): 527-536. DOI: 10.1093/aob/mcm145.

Pavlovic A, Slovakova L, Šantrucek J. 2011. Nutritional benefit from leaf litter utilization in the pitcher plant Nepenthes ampullaria. Plant, Cell \& Environment 34(11): 18651873. DOI: $\quad 10.1111 / \mathrm{j} .1365-$ 3040.2011.02382.x.

Peraturan Menteri Lingkungan Hidup dan Kehutanan Republik Indonesia No. P.20/MENLHK/SETJEN/KUM.1/6/2018.

Jenis tumbuhan dan Satwa Yang Dilindungi. 11 Juni 2018. Berita Negara Republik Indonesia Nomor 880. Jakarta.

Peraturan Pemerintah Republik Indonesia No.7 Tahun 1999. Pengawetan Jenis Tumbuhan dan Satwa. 27 Januari 1999. Jakarta.

Phillipps A, Lamb A, Lee C. 2008. Pitcher Plants of Borneo. Natural History Publications: Kinabalu.

Schulze W, Frommer WB, Ward JM. 1999. Transporters for ammonium, amino acids and peptides are expressed in pitchers of the carnivorous plant Nepenthes. The Plant Journal 17(6): 637-646. DOI: 10.1046/j.1365-313X.1999.00414.x.

Yilamujiang A, Zhu A, Ligabue-Braun R, Bartram S, Witte C, Hendrich R, Hasabe M, Schöner C, Schöner M, Kerth G, Carlini C, Mithöfe A. 2017. Coprophagous features in carnivorous Nepenthes plants: a task for ureases. Nature 7: 1-9. 